\title{
Collision sellar lesions: experience with eight cases and review of the literature
}

\author{
Maria Koutourousiou • George Kontogeorgos • \\ Pieter Wesseling · Andre J. Grotenhuis · \\ Andreas Seretis
}

Published online: 24 June 2009

(c) The Author(s) 2009. This article is published with open access at Springerlink.com

\begin{abstract}
The concomitant presence of a pituitary adenoma with a second sellar lesion in patients operated upon for pituitary adenoma is an uncommon entity. Although rare, quite a great variety of lesions have been indentified coexisting with pituitary adenomas. In fact, most combinations have been described before, but an overview with information on the frequency of combined pathologies in a large series has not been published. We present a series of eight collision sellar lesions indentified among 548 transsphenoidally resected pituitary adenomas in two Neurosurgical Departments. The histological studies confirmed a case of sarcoidosis within a non-functioning pituitary adenoma, a case of intrasellar schwannoma coexisting with growth hormone (GH) secreting adenoma, two Rathke's cleft cysts combined with pituitary adenomas, three gangliocytomas associated with GH-secreting adenomas, and a
\end{abstract}

M. Koutourousiou $(\bowtie) \cdot$ A. Seretis

Department of Neurosurgery,

G. Gennimatas Athens General Hospital,

154 Messogion Ave, 11527 Athens, Greece

e-mail: mkoutourousiou@yahoo.gr

G. Kontogeorgos

Department of Pathology,

G. Gennimatas Athens General Hospital,

Athens, Greece

P. Wesseling

Department of Pathology, UMC St Radboud,

Nijmegen, The Netherlands

A. J. Grotenhuis

Department of Neurosurgery, UMC St Radboud,

Nijmegen, The Netherlands case of a double pituitary adenoma. The pertinent literature is discussed with emphasis on pathogenetic theories of dual sellar lesions. Although there is no direct evidence to confirm the pathogenetic relationship of collision sellar lesions, the number of cases presented in literature makes the theory of an incidental occurrence rather doubtful. Suggested hypotheses about a common embryonic origin or a potential interaction between pituitary adenomas and the immune system are presented.

Keywords Adenoma - Collision tumors . Nonadenomatous sellar lesions · Pituitary

\section{Introduction}

Collision tumors represent two morphologically different tumors attached to each other. Extending this definition, collision lesions refer to histologically different pathological conditions found in combination and may include neoplastic, vascular, congenital, or infectious/inflammatory lesions. The presence of a collision sellar lesion represents a very uncommon event. A preoperative diagnosis of a dual sellar pathology is very difficult, since most of the cases are presented clinically and radiologically as pituitary adenomas. The definitive diagnosis of a collision sellar lesion is determined by the histological study. Even after histological confirmation, some "combined pathologies" could be debatable given their essentially similar pathogenesis. However, a determined pathogenetic mechanism to explain the coexistence of different lesions in the sella has not been proven. The aim of this study is to report the experience of collision sellar lesions in surgical series and to emphasize on the theories of their origin and pathogenesis with review of the literature. 


\section{Materials and methods}

We retrospectively studied the histological examinations and medical files of eight patients with dual sellar lesions among 548 individuals who underwent transsphenoidal surgery (TSS) for pituitary adenomas during the last 5 years in two Neurosurgical Departments.

The pathological examination included histological, histochemical and immunocytological studies. For light microscopy, 4-6 $\mu \mathrm{m}$ sections of formalin-fixed and paraffin-embedded tissue were stained by the hematoxylin and eosin and the periodic acid-Shiff (PAS) methods. Peroxidase-antiperoxidase and avidin-biotin-peroxidase complex $(\mathrm{ABC})$ techniques were utilized to demonstrate the presence of anedohypophysial hormones. Antisera were directed against the following pituitary hormones: growth hormone (GH; dilution 1:4000), prolactin (PRL; dilution 1:3000), adrenocorticotropic hormone (ACTH; (dilution 1:2500), $\beta$-thyroid stimulating hormone ( $\beta$-TSH; dilution 1:2000), $\beta$-follicle stimulating hormone ( $\beta$-FSH; dilution 1:1500), $\beta$-luteinizing hormone ( $\beta$-LH; dilution 1:2000) and $\alpha$-subunit of glycoprotein hormones ( $\alpha$-SU; dilution 1:1500). In addition, keratin 8 (CAM 5.2, dilution 1:50, BectonDickinson, San Jose, CA, USA) was used to demonstrate the fibrous bodies. Before application of the primary antibody, sections were treated with $1 \mathrm{mg} / 100 \mathrm{ml}$ pronase E (Sigma Chemical Companies, St. Louis, MO, USA) at room temperature. Incubations with primary antibodies were carried out overnight at $4^{\circ} \mathrm{C}$. All antisera used to localize pituitary hormones were donated from the National Hormone and Pituitary Program (NHPP) Torrance, California, USA. Additional immunostains were performed using the following antisera: S-100 protein, glial fibrillary acidic protein, neuron-specific enolase, chromogranin A, synaptophysin, neurofilament protein (NFP), GH-releasing hormone. The proliferation index of the adenomas was estimated using the Ki-67 antibody (clone MIB-1).

Medical files were retrospectively reviewed. All patients were preoperatively evaluated by endocrinologists. Endocrine examination included fasting blood cortisol, ACTH, PRL, GH, insulin-like growth factor 1 (IgF1), LH, FSH, testosterone/estradiol, TSH, thyroxine (T4) and trijodothyronine (T3) serum levels.

Preoperative magnetic resonance imaging (MRI) studies of the patients were also retrospectively analyzed. Available MRI studies of the sellar region were performed with $3 \mathrm{~mm}$ scans in sagittal and coronal planes and included T1-weighted sequences, T1-weighted images after administration of gadolinium $(\mathrm{Gd})$ and $\mathrm{T} 2$-weighted images. Maximum tumor diameter and location of sellar lesion as well as the post-contrast enhancement pattern were assessed.

\section{Results}

During the last 5 years, 548 patients with pituitary adenomas were operated via TSS in two Neurosurgical Departments. In eight cases (1.46\%), a dual sellar pathology was histologically diagnosed, composed of mixed tissue elements of adenohypophysial adenoma and a second sellar lesion, of either adenomatous or nonadenomatous origin. The cohort included five females and three males with median age of 48 years (range 38-76 years). Based on clinical and radiological findings, all patients underwent TSS with a preoperative diagnosis of pituitary adenoma.

The histological studies defining the concomitance of a pituitary adenoma with a second sellar lesion are summarised in Table 1. The histological diagnosis confirmed a case of sarcoidosis within a non-functioning pituitary adenoma (NFPA) (Fig. 1), three cases of gangliocytoma associated with GH-secreting pituitary adenoma (Figs. 2, 3), a schwannoma coexisting with GH-secreting adenoma, a case of double adenoma consisting of a GH-secreting adenoma and a prolactinoma (Fig. 4), and two Rathke's cleft cysts (RCC) with a concomitant pituitary adenoma, specifically an ACTH-secreting and a NFPA adenoma (Fig. 5). The case of intrasellar schwannoma coexisting with a GHsecreting adenoma has already been accepted for publication. In case of neurosarcoidosis within an adenoma, the final diagnosis was definite when systemic pulmonary disease was determined, 3 years after the initial operation.

Table 2 provides a summary of clinical presentation, preoperative treatment, MRI findings, histological diagnoses, surgical results and adjuvant management of the eight collision sellar cases, in a mean follow up period of 37.9 months (range 18-55 months).

In every case only the pituitary adenoma was symptomatic. Six patients presented with hypersecretory symptoms and were all histologically diagnosed with a hormone-active adenoma; three of them were preoperatively treated with somatostatin analogs or dopamine agonists. Four patients presented with varying degree of pituitary insufficiency requiring hormonal replacement therapy in two of them. No symptoms characteristic of the coexisting lesion were observed in any of the cases.

On the preoperative MRI, the tumor diameter ranged between 11 and $25 \mathrm{~mm}$. In two cases, a parasellar extension of the tumor was observed. All lesions enhanced either homogenously or heterogeneously after Gd administration. None the MRI findings, summarized in Table 2, proclaimed the presence of a collision sellar lesion, so that in every case the preoperative diagnosis was a pituitary adenoma (Figs. 6, 7).

One patient (No. 2) underwent a second TSS 3 years after the initial operation due to the recurrence of the lesion; the histological diagnosis of the second operation 
Table 1 Histological studies defining the concomitant of a pituitary adenoma with a second sellar lesion

\begin{tabular}{|c|c|c|c|}
\hline No. & Pituitary adenoma & 2nd sellar lesion & Conclusion \\
\hline 1 & Basophilic ACTH immunoreactive & $\begin{array}{l}\text { PAS-positive mucin, cystic wall with } \\
\text { columnar epithelium }\end{array}$ & $\begin{array}{l}\text { ACTH-secreting pituitary adenoma } \\
\text { coexisting with RCC }\end{array}$ \\
\hline 2 & $\begin{array}{l}\text { Chromophobic immunonegative (null cell) } \\
\text { adenoma }\end{array}$ & $\begin{array}{l}\text { Granoulomas formation without necrosis } \\
\text { possibly secondary to sarcoidosis }\end{array}$ & $\begin{array}{l}\text { Neurosarcoidosis within a null cell } \\
\text { pituitary adenoma }\end{array}$ \\
\hline 3 & $\begin{array}{l}\text { Chromophobic sparsely granulated GH } \\
\text { immunoreactive, locally immunopositive } \\
\text { for PRL, immunoreactive for NFP }\end{array}$ & Ganglion cells within a fibrillary substrate & $\begin{array}{l}\text { Gangliocytoma combined with a GH- } \\
\text { secreting pituitary adenoma }\end{array}$ \\
\hline 4 & $\begin{array}{l}\text { Chromophobic sparsely granulated GH } \\
\text { immunoreactive }\end{array}$ & $\begin{array}{l}\text { Well-circumscribed schwannoma Antoni } \\
\text { A type with parallel-organised spindle- } \\
\text { shaped cells around hypocellular areas } \\
\text { ("Verocay bodies") }\end{array}$ & $\begin{array}{l}\text { GH-secreting pituitary adenoma } \\
\text { coexisting with an intrasellar } \\
\text { schwannoma }\end{array}$ \\
\hline 5 & $\begin{array}{l}\text { Chromophobic sparsely granulated GH } \\
\text { immunoreactive, locally immunopositive for } \\
\text { PRL and } \alpha \text {-SU, immunoreactive for NFP }\end{array}$ & $\begin{array}{l}\text { Large ganglion cells embedded in a dense } \\
\text { neuropil substrate }\end{array}$ & $\begin{array}{l}\text { Gangliocytoma combined with a GH- } \\
\text { secreting pituitary adenoma }\end{array}$ \\
\hline 6 & $\begin{array}{l}\text { Chromophobic, GH immunoreactive, locally } \\
\text { immunopositive for } \alpha \text {-SU }\end{array}$ & $\begin{array}{l}\text { Chromophobic PRL immunoreactive } \\
\text { pituitary adenoma }\end{array}$ & $\begin{array}{l}\text { Double adenoma consisting of a GH- and } \\
\text { a PRL-secreting pituitary adenoma }\end{array}$ \\
\hline 7 & $\begin{array}{l}\text { Chromophobic, immunoreactive mainly } \\
\text { for } \beta \text {-LH and locally for } \beta \text {-FSH }\end{array}$ & $\begin{array}{l}\text { Cystic formation of Rathke's cleft with a } \\
\text { diameter of } 0.1 \mathrm{~cm} \text {, PAS-negative }\end{array}$ & $\begin{array}{l}\text { Gonadotroph pituitary adenoma } \\
\text { coexisting with RCC }\end{array}$ \\
\hline 8 & $\begin{array}{l}\text { Chromophobic sparsely granulated GH } \\
\text { immunoreactive, locally immunopositive } \\
\text { for PRL, immunoreactive for NFP }\end{array}$ & $\begin{array}{l}\text { Ganglion cells embedded in a fibrillary } \\
\text { substrate }\end{array}$ & $\begin{array}{l}\text { Gangliocytoma combined with } \\
\text { a GH-secreting pituitary adenoma }\end{array}$ \\
\hline
\end{tabular}

$\alpha$-SU $\alpha$-subunit of glycoprotein hormones, $\beta$-FSH $\beta$-follicle stimulating hormone, $\beta$ - $L H \beta$-luteinizing hormone, $A C T H$ adrenocorticotropic hormone, $G H$ growth hormone, NFP neurofilament protein, $P A S$ periodic acid-Shiff, $P R L$ prolactin, $R C C$ Rathke's cleft cyst

${ }^{a}$ The final diagnosis of neurosarcoidosis was determined 3 years after surgery when the pulmonary disease was verified

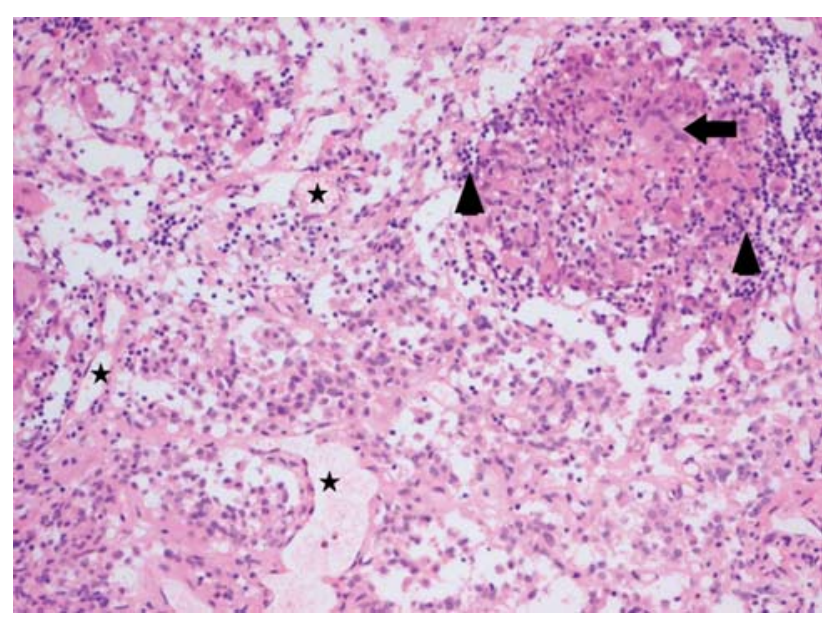

Fig. 1 Patient No. 2. Pituitary null cell adenoma combined with granulomatous inflammation due to neurosarcoidosis. The pituitary adenoma consists of highly vascularized tissue (asterisks in some vessel lumina) and a monomorphous population of epitheloid tumor cells with eosinophilic cytoplasm; in the upper right hand corner a non-necrotizing granuloma is present consisting of histiocytes, some multinucleate giant cells (example indicated by arrow) and collections of small lymphocytes (arrowheads). Hematoxylin \& Eosin staining $\times 100$

confirmed the same dual pathology of sarcoidosis within a pituitary adenoma. Further treatment for the rest of the cases was decided according to the surgical outcome and the histological study.

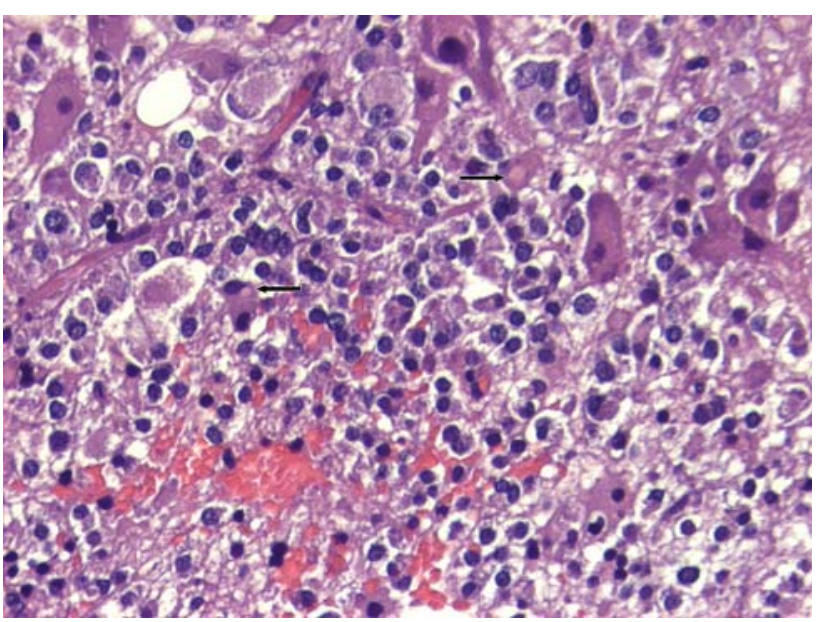

Fig. 2 Patient No. 5. Gangliocytoma coexisting with sparsely granulated somatotroph adenoma. The adenoma part consists of small chromophobic cells with typical cytoplasmic fibrous bodies (arrows). The gangliocytic component comprises large, polyhedral, mature ganglion cells with abundant cytoplasm and spheroid nuclei. Hematoxylin \& Eosin staining $\times 20$

\section{Discussion}

The occurrence of collision sellar lesions is very uncommon accounting for $1.46 \%$ in the present series. Given the clinical and imaging similarities to pituitary adenomas, the diagnosis of a dual pathological condition of the sella is 


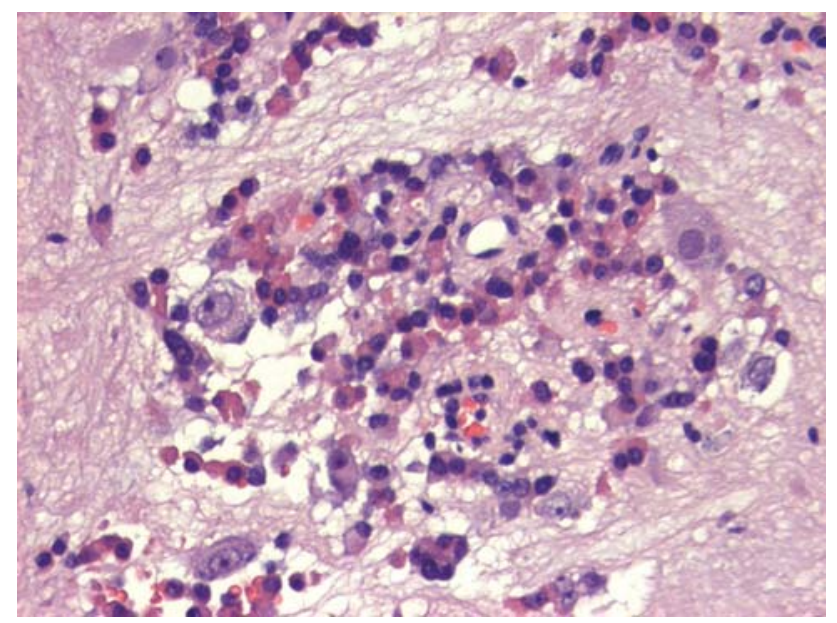

Fig. 3 Patient No. 8. Ganglion cells admixed with acidophil cells of a densely granulated somatotroph adenoma. Note the presence of prominent nucleoli in ganglion cell and the fibrillary neuropil in the stroma. Hematoxylin \& Eosin staining $\times 20$

usually based on the histological study. To date, very few surgical series have been reported describing specific combinations of sellar lesions like a double pituitary adenoma [1, 2], a combination of an adenoma with RCC [3-5] or a gangliocytoma associated with a pituitary adenoma [6-8]. Mainly, case reports have been published, demonstrating the concomitance of two different pathologies within the sella. Most publications include a pituitary adenoma coexisting with a second lesion like a craniopharyngioma [9], arachnoid cyst [10], colloid cyst [11], epidermoid cyst [12], lymphocytic hypophysitis [13, 14], granulomatous hypophysitis [15], sarcoidosis within a pituitary adenoma [16] and metastatic carcinoma to pituitary adenoma [17-19]. Although it could be claimed that these entities would be expected as incidental occurrences, the great variety of coexisting lesions with a pituitary adenoma make this hypothesis rather doubtful. Many

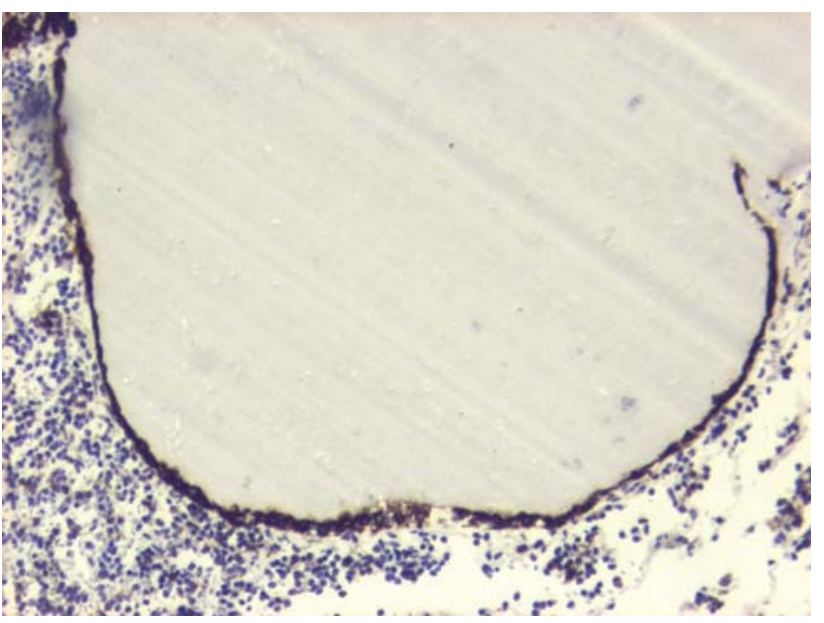

Fig. 5 Patient No. 7. Rathke's cleft cyst with single cell lining immunoreactive for keratin 8 . The lumen contains colloidal material. The surrounded tissue corresponds to chromophobic pituitary adenoma. Avidin-biotin-peroxidase complex method $\times 10$

theories have suggested explanations for potential pathogenetic relationship between the concomitant lesions. Still, clear evidence of this relation has not been proven.

A review for each collision sellar lesion encountered in our series is herein discussed with emphasis on possible pathogenetic origins.

Pituitary adenoma and concomitant Rathke's Cleft Cyst

The incidental finding of small, asymptomatic RCC in autopsy specimens of normal pituitary glands climbs up to $33 \%$ [20]. However, the coexistence of RCC with a pituitary adenoma is rare. In a large clinicopathologic study of 464 cases [3], the rate of coincidence was $1.7 \%$, and in a recent report [4] only 4 concomitant RCC were identified among 782 cases with known pituitary adenoma $(0.51 \%)$. Although Sumida et al. [5] reported a coincidence rate of

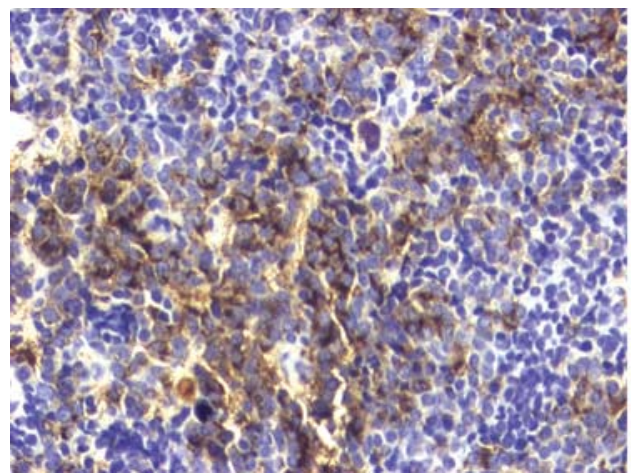

Fig. 4 Patient No. 6. Left: Tissue fragment of chromophobic adenoma with focal immunoreactivity for GH, typical for the sparsely granulated variant of somatotroph adenomas. Avidin-biotin-peroxidase complex method $\times 20$. Right: Another fragment from the same

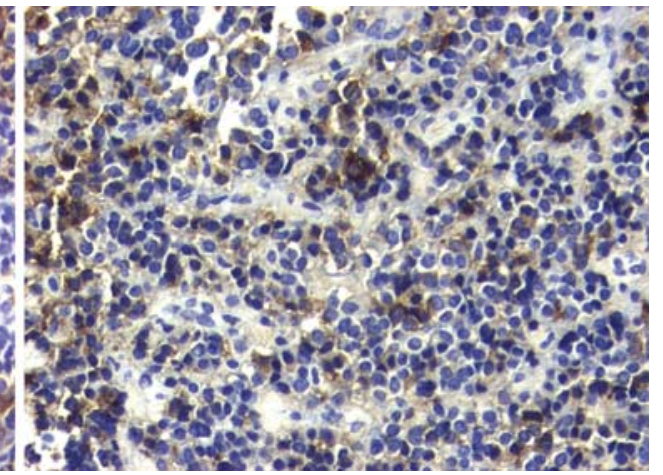

specimen immunopositive for PRL, with the characteristic paranuclear, dot-like localization of chromogen. Avidin-biotin-peroxidase complex method $\times 20$ 


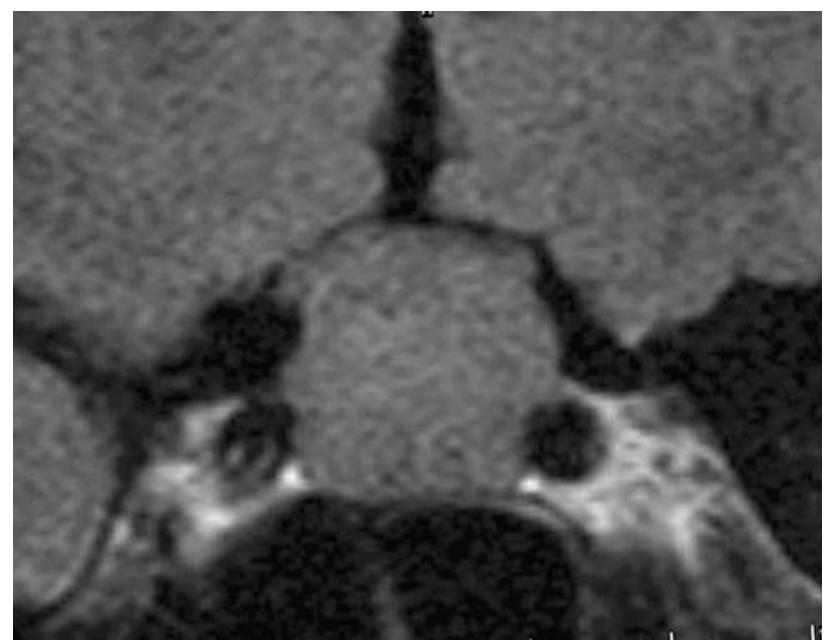

Fig. 6 Patient No. 2. Preoperative coronal T1-weighted MRI showing a sellar lesion of $20 \mathrm{~mm}$ with suprasellar extension suggesting a preoperative diagnosis of a non-functioning pituitary adenoma

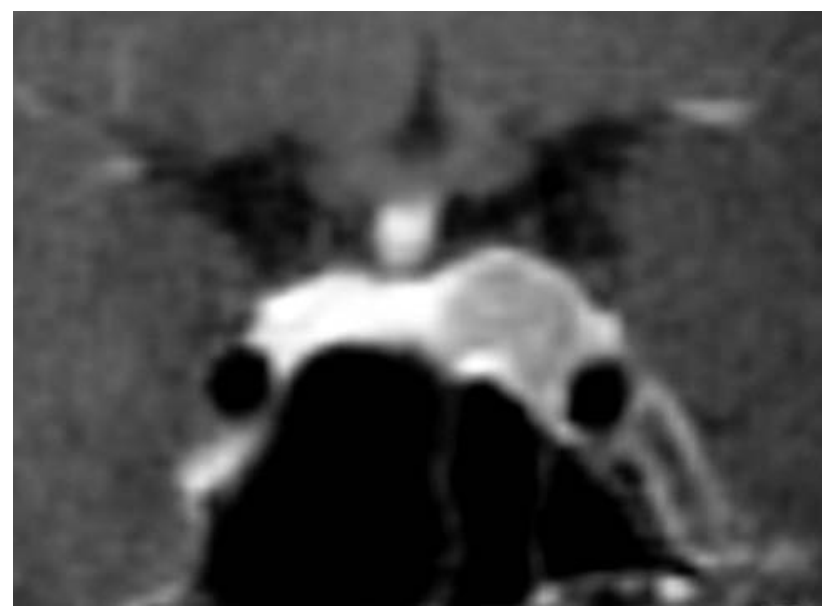

Fig. 7 Patient No. 8. Preoperative coronal T1-weighted MRI demonstrating a sellar lesion attached to the left cavernous sinus, stretching the pituitary gland to the right and slightly deviating the pituitary stalk. Given the clinical presentation, the lesion was considered to be a GH-secreting pituitary adenoma

$3.5 \%$ in 228 patients with pituitary adenomas, their study was based on radiological findings and only two among eight presumed RCC were histologically confirmed, making this high percentage rather questionable. In our database, two cases of collision RCC and pituitary adenoma were histologically diagnosed (No. 1 and 7) giving a percentage of $0.74 \%$ among the patients operated for pituitary adenomas.

On a recent review of the literature, Noh et al. [4] identified only 32 reported cases of a pituitary adenoma and a concomitant RCC. According to this review, most adenomas were prolactinomas. In total, the reported cases included 13 prolactinomas, $9 \mathrm{GH}-, 2$ ACTH-secreting adenomas, 3 mixed adenomas and 5 NFPA. In all these cases only the pituitary adenomas were symptomatic, which was true in our two patients as well. However, only in 26 among 32 cases the diagnosis of a coexisted RCC was confirmed histologically [4].

A preoperative diagnosis of these collision sellar lesions based on MRI findings is very difficult $[4,5]$. When radiologically discriminated, RCC show variable position, size, and signal intensity on MRI, and there is no specific pattern of pituitary displacement $[4,5]$. The MRI intensity of RCC depends on protein concentration [21, 22]. Only in 15 of 32 reported cases of collision RCC and pituitary adenoma [4] the lesion contained two different signal intensities on MRI. In none of our cases the lesions were radiologically distinguishable from each other.

The pathogenesis of these rare collision lesions is still unclear. Initially, in 1978, Kepes [23] described a transitional cell tumor of the pituitary gland developing from a RCC, considering that the tumor was derived from "transitional" cells between the lining cells of Rathke's cleft and the glandular cells of the anterior pituitary. This theory was rejected by Ikeda et al. [24] who proved that the tumor described by Kepes [23] corresponded to an early developmental stage of the pituitary anterior lobe and that a cyst within a pituitary adenoma differs from cysts found in the embryonic stage of the pituitary gland. Another theory concerning the pathogenesis of the concurrence of prolactinoma and RCC [25] suggested a prolactin cell stimulation from an existing RCC which results in a secondary adenoma formation. We disagree with this theory as it is against the monoclonal origin of pituitary adenomas $[26,27]$. Furthermore, such a theory cannot be applied when the pituitary adenoma coexisting with a RCC is other than a prolactinoma, as happened in our two cases.

In conclusion, the pathogenesis of compound pituitary adenomas and RCC remains to be clarified. Rathke's pouch gives rise to the anterior pituitary lobe via proliferation of its anterior wall, and the anterior pituitary lobe is known to give rise to pituitary adenomas through clonal alteration [3, 26, 27]. Therefore, RCC deriving from remnants of Rathke's pouch $[28,29]$ and pituitary adenomas could be suggested to have a common embryonic origin. However, this histogenetic link between RCC and pituitary adenomas has not been proven yet.

\section{Multiple pituitary adenomas}

Multiple adenomas are defined as morphologically or immunohistologically distinct adenomas found in the same specimen [1] and have to be distinguished from mixed adenomas, where mixed cell populations demonstrates immunoreactivity for two or more hormones $[1,30]$. The incidence of multiple pituitary adenomas in autopsies is not 


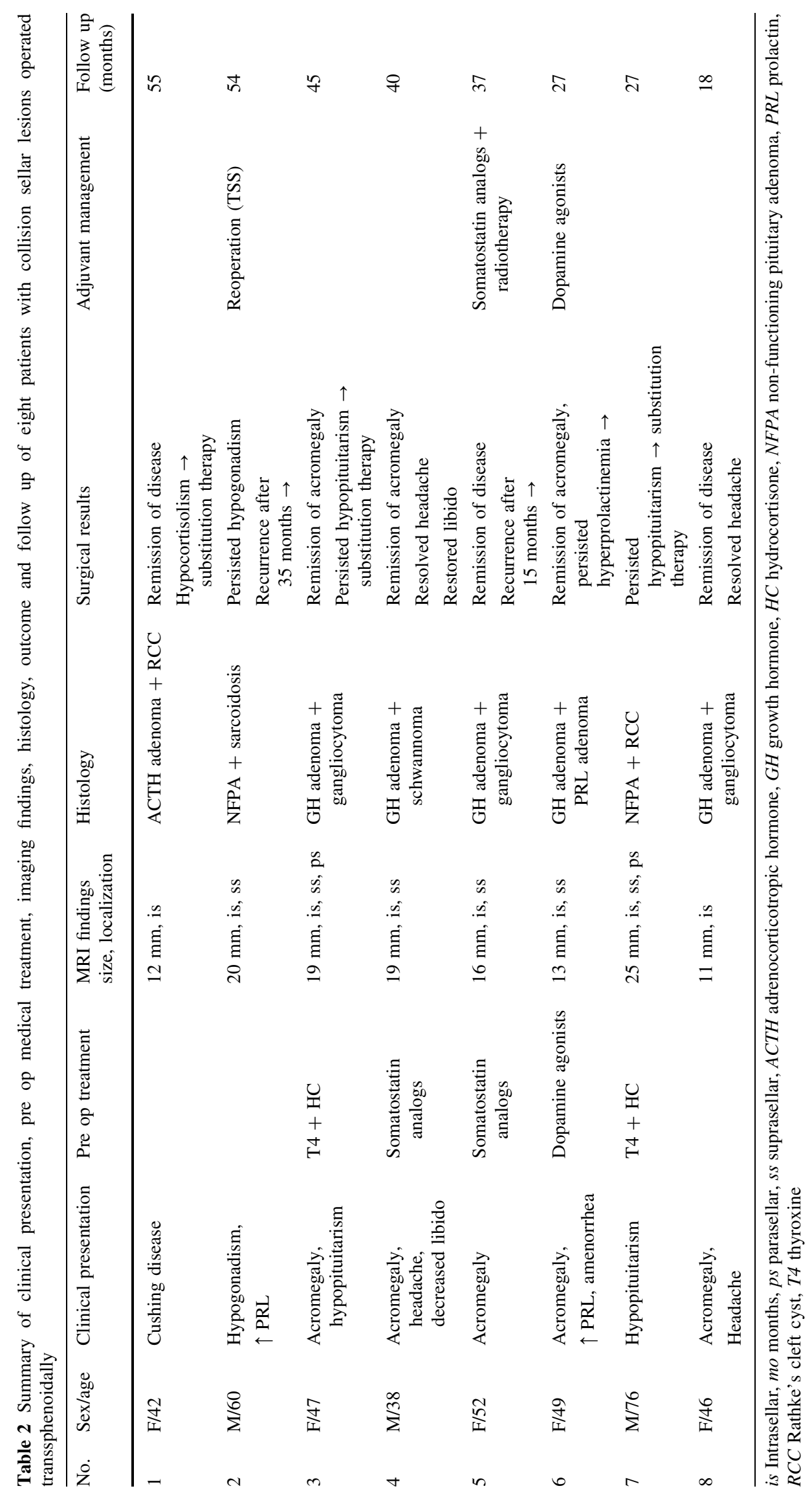


so rare and the diagnostic criteria include tumors that exhibit different immunoreactivities or tumors with the same immunoprofile, which are located in different anatomical sites and show dissimilar histological patterns [31]. Kontogeorgos et al. [31], in the largest ever reported autopsy study of more than 9,300 pituitary glands, identified 20 cases of multiple adenomas accounting of $0.9 \%$ of incidentally pituitary adenoma cases. Other authors have reported higher rates of multiple adenomas in autopsy, like 7 [32], 10\% [33], or even more than $10.5 \%$ [34].

In surgical series, the incidence of multiple adenomas is lower compared with autopsy series and this is mainly due to fragments of surgical specimens [1]. Their initial diagnosis must be based upon light microscopic criteria, such as demonstration of distinct pattern variation and differences in cytological features and hormone content. Thus, adenoma fragments showing dissimilar histological and ultrastructural features can be considered to represent two distinct adenomas. Alternatively, histologically similar tissue fragments may correspond to separate adenomas if they exhibit different hormone immunoreactivities and ultrastructural features [1]. In a large surgical cohort of more than 3,000 resected pituitary adenomas the percentage of double adenomas was $0.37 \%$ [1]. In our experience the rate was $0.18 \%$. This low incidence in the present limited number of cases may reflect the significant diagnostic problem when the surgical specimen contains only minute fragments of the second adenoma. Actually, a significant number of supernumerary pituitary adenomas is likely to remain undiagnosed in surgical series [1]. However, rates as high as $1.3 \%$ have been published [2]. The commonest hormone-active adenoma identified in surgical series of double adenomas is GH-secreting adenoma [1,2], as in our report.

Given the frequency of pituitary incidentalomas, a coincidental occurrence of a second adenoma could be expected. However, some theories trying to provide a causal link between multiple pituitary adenomas have been suggested. One is the occurrence of different clonal proliferation within originally one adenoma resulting in partial transformation of the adenoma to another phenotype $[1,2]$. Although it has been shown that most pituitary adenomas are monoclonal in origin, the possibility exists that new clones may develop during the progression of an adenoma $[35,36]$. Thus, it may be that adenoma profiles are unstable and subject to change under modified microenvironmental conditions [1]. Another theory suggests that one adenoma can induce the formation of another adenoma. This hypothesis can be better applied in cases of GH-secreting adenomas which release substances like $\mathrm{GH}$ and $\mathrm{IgF} 1$ that may promote the secondary adenoma growth $[1,2]$. Furthermore, in a recent study [27], several pituitary-driven growth factors had been shown to induce pituitary hyperplasia with or without ultimate adenoma development when expressed in transgenic mice. Last, the role of altered hypothalamic function due to a primary pituitary tumor can be considered in the development of a new adenoma. Occasionally, multifocal polyclonal pituitary adenomas associated with hyperprolactinemia may arise either due to extrinsic changes in hypothalamic factors, or to pituitary stalk compression, blocking lactotroph inhibition by dopamine [27].

None of the proposed pathogenetic mechanisms have been proven. Resent promising studies [27] mainly based on molecular analysis provide new insights in understanding the multidirectional mechanisms underlying the pituitary adenomatogenesis. Main factors considered in pituitary tumorigenesis include both intrinsic pituicyte alterations and altered availability of regulatory factors including hypothalamic hormones, peripheral hormones, and paracrine growth factors.

Gangliocytoma associated with pituitary adenoma

Gangliocytomas are rare entities of undetermined histogenesis [7, 8, 37, 38]. Gangliocytomas associated with pituitary adenomas are mixed tumors composed of both adenomatous and gangliocytic elements; ganglion cells are described within a variably dense fibrillary substrate and are frequently associated with adenomatous proliferation of pituitary cells [8]. To date, approximately 65 cases have been reported [8]. In a series of 1,322 sellar lesions, gangliocytomas associated with pituitary adenomas were estimated to account $0.52 \%$ of sellar tumors [8]. Other authors report an incidence of $1.26 \%$ [39]. In our experience, the percentage was $0.55 \%$.

Most patients are females and up to three-quarters of them are preoperatively diagnosed as having GH-secreting pituitary adenoma [7, 8, 38, 39], as was true for all three cases in our series (No. 3, 5 and 8). In a few reported cases the tumor presented with symptoms of Cushing's disease or of excessive PRL secretion [7, 38, 40, 41]. In GH-producing tumors, the neuronal component is almost exclusively associated with a sparsely granulated somatotroph adenoma [7, 8, 38], a feature found in all three cases in this series. Neither imaging nor intraoperative findings reveal any differences between gangliocytoma and pituitary adenoma, so that the initial diagnosis is that of a GH-secreting pituitary adenoma [8].

The origin of gangliocytomas is still unclear. The theory of an incidental finding was supported by the hypothesis of abnormal migration of hypothalamic neurons within the adenohypophysial parenchyma during the early phase of embryogenesis [42]. Thus, these mixed tumors may represent an incidental concurrence of a pituitary adenoma in a pre-existing neuronal choristoma. Another theory 
supports that pituitary hormone-releasing hypothalamic hormones locally produced by the ganglion cells promote the adenoma formation by adenohypophysial cells stimulation. This hypothesis is strengthened by the presence of hypophysiotropic hormones within the neurons of gangliocytomas corresponding to the relevant pituitary hormones secreted by adenoma cells $[6,43]$. However, lack of correlation between adenoma cell type and the corresponding releasing hypothalamic hormone within ganglion cells in some tumors weakens this hypothesis [8]. A third hypothesis suggests the origin of the neuronal component from neuronal differentiation of a pre-existing pituitary adenoma reporting the presence of transitional cell forms between neurons and adenohypophysial cells [44]. Vidal et al. [45] supports the assumption of neuronal metaplasia of pituitary adenoma cells describing that somatotrophs exhibit plasticity and under certain conditions they can undergo transdifferentiation. Moreover, the documented presence of nerve growth factor (NGF) in various adenoma cell types [46] and the evidence that NGF receptors are present in adenoma cells [47] further supports this theory. Although this assumption may be challenging, we remain critical, as it is difficult to completely understand the transformation of a neoplastic pituitary cell to a well-differentiated mature neuron with the dominating embryological concepts [8].

Recently, a common origin of both adenomatous and neuronal component of the pituitary gangliocytomas has been suggested [8]. The adult pituitary gland has been proven to contain a cell population displaying characteristics of stem/progenitor cell [48]. Kontogeorgos et al. [8] reappraised this theory, based on the common origin of both neuronal and adenohypophysial components from uncommitted stem/progenitor cells capable of multidirectional differentiation. In this study, the authors concluded that the presence of NFP in the adenoma cell compartment of gangliocytomas indicates neuronal differentiation in adenoma cells, suggesting a common origin for neuronal and pituitary adenoma cell elements in gangliocytomas. In all our three specimens, the adenoma compartment was examined and found immunoreactive for NFP, further supporting the later theory.

Pituitary adenoma concomitant with intrasellar schwannoma

Intrasellar schwannomas are extremely rare and to date less than 15 cases have been reported [49-61]. In none of these cases, a preoperative diagnosis was possible based on MRI evaluation or clinical presentation. The origin of intrasellar schwannomas remains unclear, however, some theories concerning their histogenesis have been proposed. Extension in the sella from a cranial nerve within the cavernous sinus could be possible [53, 59], although, in this case, cranial nerve symptoms must be expected. A very interesting theory has been suggested by Bleys et al. [62] considering a possible origin of intrasellar schwannomas from the lateral sellar nerve plexus. Other hypotheses about intrasellar schwannomas' origin include perivascular nerve plexus, multipotential mesenchymal cells, displaced neural crest cells and ectopic Schwann cells $[56,63]$.

Our case of coexistent GH-secreting pituitary adenoma with an intrasellar schwannoma (No. 4) is recently published [64] and represents the only documented report of such an uncommon entity. The literature provides no data explaining a possible interaction between $\mathrm{GH}-$ secreting pituitary adenomas and intrasellar schwannomas, or a possible common origin of the two tumors. Thus, their coexistence should be considered incidental finding.

Sarcoidosis within a pituitary adenoma

Neurosarcoidosis is present in $5-15 \%$ of patients with systemic disease mainly affecting the hypothalamic-pituitary region through lymphocytic and granulomatous infiltrates of the basilar meninges or as part of local or diffuse disease of the CNS parenchyma [65]. However, the presence of neurosarcoidosis within a pituitary adenoma has only been reported once in literature [16]. In the case of Rubin et al. [16], the patient had already lung disease at the time of presentation. In our patient (No. 2), pulmonary disease was manifested 3 years after the initial TSS and remained clinically silent, no indicating treatment. In none case, the preoperative MRI findings were distinguishable from a pituitary adenoma. In both patients, pituitary insufficiency remained after treatment, requiring replacement therapy. Interestingly, recurrence in our patient occurred in both tumors population.

Although there is no proven mechanism to explain the coexistence of sarcoid and pituitary adenoma, interesting theories concerning the pathogenesis of pituitary inflammation [66] and the potential interaction between pituitary adenomas and the immune system have been proposed [14]. In their article, Moskowitz et al. [14] discuss the concurrence of lymphocytic hypophysitis and other intrasellar lesions, such as pituitary adenomas. The authors support the theory that normal and neoplastic pituitary can stimulate an inflammatory reaction via expression of multiple cytokines, which play an incompletely understood role in pituitary physiology. Cases of sarcoidosis have been already reported in the setting of known granulomatous inflammation of the target organs [67]. Whether the presence of a pituitary adenoma can stimulate local inflammation disorders predisposing to sarcoid formation is an 
assumption that needs to be proven. However, if this hypothesis is correct it could explain the evidence of sarcoidosis within a pituitary adenoma.

\section{Conclusion}

"Combined sellar pathology" in case of patients operated upon for a pituitary adenoma is extremely rare. However, a great variety of lesions can coexist with pituitary adenomas and referred to as "collision sellar lesions". Histological studies are essential to confirm the diagnosis. Still no proven pathogenetic mechanism has explained the relationship between a pituitary adenoma and a second sellar lesion. However, interesting theories have been suggested. Progress in molecular genetics, new technologies and further research will shed more light on the mechanisms of pituitary adenomatogenesis/tumorigenesis and their potential interaction.

Acknowledgments The authors are indebt to the National Hormone and Pituitary Program (NHPP) Torrance, California, USA for donating (to G. Kontogeorgos) all pituitary hormone antisera.

\section{Financial sources none}

Open Access This article is distributed under the terms of the Creative Commons Attribution Noncommercial License which permits any noncommercial use, distribution, and reproduction in any medium, provided the original author(s) and source are credited.

\section{References}

1. Kontogeorgos G, Scheithauer BW, Horvath E, Kovacs K, Lloyd RV, Smyth HS et al (1992) Double adenomas of the pituitary: a clinicopathological study of 11 tumors. Neurosurgery 31:840849

2. Sano T, Horiguchi H, Xu B, Li C, Hino A, Sakaki M et al (1999) Double pituitary adenomas: six surgical cases. Pituitary 1:243250

3. Nishio S, Mizuno J, Barrow DL, Takei Y, Tindall GT (1987) Pituitary tumors composed of adenohypophyseal adenoma and Rathke's cleft cyst elements: a clinicopathological study. Neurosurgery 21:371-377

4. Noh SJ, Ahn JY, Lee KS, Kim SH (2007) Pituitary adenoma and concomitant Rathke's cleft cyst. Acta Neurochir (Wien) 149:1223-1228

5. Sumida M, Migita K, Tominaga A, Iida K, Kurisu K (2001) Concomitant pituitary adenoma and Rathke's cleft cyst. Neuroradiology 43:755-759

6. Asa SL, Scheithauer BW, Bilbao JM, Horvath E, Ryan N, Kovacs $\mathrm{K}$ et al (1984) A case for hypothalamic acromegaly: a clinicopathological study of six patients with hypothalamic gangliocytomas producing growth hormone-releasing factor. J Clin Endocrinol Metab 58:796-803

7. Geddes JF, Jansen GH, Robinson SFD, Gömöri E, Holton JL, Monson JP et al (2000) "Gangliocytomas" of the pituitary. A heterogeneous group of lesion with differing histogenesis. Am J Pathol 24:607-613
8. Kontogeorgos G, Mourouti G, Kyrodimou E, Liapi-Avgeri G, Parasi E (2006) Ganglion cell containing pituitary adenomas: signs of neuronal differentiation in adenoma cells. Acta Neuropathol 112:21-28

9. Karavitaki N, Scheithauer BW, Watt J, Ansorge O, Moschopoulos M, Llaguno AV et al (2008) Collision lesions of the sella: co-existence of craniopharyngioma with gonadotroph adenoma and of Rathke's cleft cyst with corticotroph adenoma. Pituitary 11:317-323

10. Güzel A, Er U, Tatli M, Uzunlar AK, Belen D, Bavbek M (2007) Pituitary adenoma coexisting with a suprasellar arachnoid cyst. Turk Neurosurg 17:138-141

11. Nomikos P, Buchfelder M, Fahlbusch R (1992) Intra- and suprasellar colloid cysts. Pituitary 2:123-126

12. Kaspera W, Bierzyńska-Macyszyn G, Majchrzak H (1998) A case of parasellar tumor with double histological texture: chromophobe pituitary adenoma and epidermoid cyst. Neurol Neurochir Pol 32:987-996 (Polish)

13. Ballian N, Chrisoulidou A, Nomikos P, Samara S, Kontogeorgos G, Kaltsas GA (2007) Hypophysitis superimposed on a nonfunctioning pituitary adenoma: diagnostic clinical, endocrine and radiologic features. J Endocrinol Invest 30:677-683

14. Moskowitz SI, Hamrahian A, Prayson RA, Pineyro M, Lorenz RR, Weil RJ (2006) Concurrent lymphocytic hypophysitis and pituitary adenoma. Case report and review of the literature. J Neurosurg 105:309-314

15. Saeger W, Hofmann BM, Buslei R, Buchfelder M (2007) Silent ACTH cell adenoma in coincidence with granulomatous hypophysitis-a case report. Pathol Res Pract 203:221-225

16. Rubin MR, Bruce JN, Khandji AG, Freda PU (2001) Sarcoidosis within a pituitary adenoma. Pituitary 4:195-202

17. Bret P, Jouvet A, Madarassy G, Guyotat J, Trouillas J (2001) Visceral cancer metastasis to pituitary adenoma: report of two cases. Surg Neurol 55:284-290

18. Post KD, McCormick PC, Hays AP, Kandji AG (1988) Metastatic carcinoma to pituitary adenoma. Report of two cases. Surg Neurol 30:286-292

19. Ramsay JA, Kovacs K, Scheithauer BW, Ezrin C, Weiss MH (1988) Metastatic carcinoma to pituitary adenomas: a report of two cases. Exp Clin Endocrinol 92:69-76

20. El-Mahdy W, Powell M (1998) Transsphenoidal management of 28 symptomatic Rathke's cleft cysts, with special reference to visual and hormonal recovery. Neurosurgery 42:7-17

21. Hayashi Y, Tachibana O, Muramatsu N, Tsuchiya H, Tada M, Arakawa Y et al (1999) Rathke cleft cyst: MR and biochemical analysis of cyst content. J Comput Assist Tomogr 23:34-38

22. Ikeda H, Yoshimoto $T$ (2002) Clinicopathological study of Rathke's cleft cyst. Clin Neuropathol 21:82-91

23. Kepes JJ (1978) Transitional cell tumour of the pituitary gland developing from a Rathke's cleft cyst. Cancer 41:337-343

24. Ikeda H, Yoshimoto T, Katakura R (1992) A case of Rathke's cleft cyst within a pituitary adenoma presenting with acromegalydo "transitional cell tumours of the pituitary gland" really exist? Acta Neuropathol (Berl) 83:211-215

25. Trokoudes KM, Walfish PG, Holgate RC, Pritzker KPH, Schwartz ML, Kovacs K (1978) Sellar enlargement with hyper-prolactinemia and a Rathke's cleft pouch cyst. JAMA 240:471-473

26. Asa SL, Ezzat S (1998) The cytogenesis and pathogenesis of pituitary adenomas. Endocr Rev 19:798-827

27. Melmed S (2003) Mechanisms for pituitary tumorigenesis: the plastic pituitary. J Clin Invest 112:1603-1618

28. Fager CA, Carter H (1966) Intrasellar epithelial cysts. J Neurosurg 24:77-81

29. Harrison MJ, Morgello S, Post KD (1994) Epithelial cystic lesions of the sellar and parasellar region: a continuum of ectodermal derivatives? J Neurosurg 80:1018-1025 
30. Kovacs K, Horvath E (1986) Tumors of the pituitary gland. In: Atlas of tumor pathology. 2nd Series, Fascicle 21, Armed Forces Institute of Pathology, Washington, DC

31. Kontogeorgos G, Kovacs K, Horvath E, Scheithauer BW (1991) Multiple adenomas of the human pituitary. A retrospective autopsy study with clinical implications. J Neurosurg 74:243-247

32. McComb DJ, Ryan N, Horvath E, Kovacs K (1983) Subclinical adenomas of the human pituitary. New light on old problems. Arch Pathol Lab Med 107:488-491

33. Kovacs K, Ryan N, Horvath E, Singer W, Ezrin C (1980) Pituitary adenomas in old age. J Gerontol 35:16-22

34. Heitz PU (1979) Multihormonal pituitary adenomas. Horm Res 10:1-13

35. Herman V, Fagin J, Gonsky R, Kovacs K, Melmed S (1990) Clonal origin of pituitary adenomas. J Clin Endocrinol Metab 71:1427-1433

36. Jacoby LB, Hedley-Whyte ET, Pulaski K, Seizinger BR, Martuza RL (1990) Clonal origin of pituitary adenomas. J Neurosurg 73:731-735

37. Asa SL, Kontogeorgos G, Sano T, Kovacs K, Lloyd RV, Trouillas J (2004) Gangliocytoma. In: DeLellis RA, Heitz P, Lloyd $\mathrm{RV}$, Eng C (eds) WHO classification of tumours of the endocrine organs: pathology and genetics of endocrine organs, IARC Press, Lyon, p 40

38. Towfighi J, Salam MM, McLendon RE, Powers S, Page RB (1996) Ganglion-cell-containing tumors of the pituitary gland. Arch Pathol Lab Med 120:369-377

39. Kurosaki M, Saeger W, Lüdecke DK (2002) Intrasellar gangliocytomas associated with acromegaly. Brain Tumor Pathol 19: 63-67

40. Puchner MJ, Lüdecke DK, Valdueza JM, Saeger W, Willig RP, Stalla GK et al (1993) Cushing's disease in a child caused by a corticotropin-releasing hormone-secreting intrasellar gangliocytoma associated with an adrenocorticotropic hormone-secreting pituitary adenoma. Neurosurgery 33:920-925

41. Saeger W, Puchner MJA, Lüdecke DK (1994) Combined sellar gangliocytoma and pituitary adenoma in acromegaly or Cushing's disease. A report of three cases. Virchows Arch 425:93-99

42. Harding B, Capp AJ (1997) Malformations. In: Graham DI, Landos PL (eds) Greenfield's neuropathology, 6th edn. Oxford University Press, New York, pp 397-533

43. Sano T, Asa SL, Kovacs K (1988) Growth hormone-releasing hormone-producing tumors: clinical, biochemical, and morphological manifestations. Endocr Rev 3:357-373

44. Horvath E, Kovacs K, Scheithauer BW, Lloyd RV, Smyth HS (1994) Pituitary adenoma with neuronal choristoma (PANCH). Composite lesion or lineage infidelity? Ultrastruct Pathol 18:565-574

45. Vidal S, Horvath E, Kovacs K, Lloyd RV, Smyth HS (2001) Reversible transdifferentiation: interconversion of somatotrophs and lactotrophs in pituitary hyperplasia. Mod Pathol 14:20-28

46. Scheithauer BW, Horvath E, Kovacs K, Lloyd RV, Stefaneanu L, Buchfelder $M$ et al (1999) Prolactin-producing adenoma and carcinoma with neuronal components-a metaplastic lesion. Pituitary 1:197-205

47. Missale C, Boroni F, Sigala S, Buriani A, Fabris M, Leon A et al (1996) Nerve growth factor in the anterior pituitary: localization in mammotroph cells and cosecretion with prolactin by a dopamineregulated mechanism. Proc Natl Acad Sci USA 93:4240-4245
48. Chen J, Hersmus N, Van Duppen V, Caesens P, Denef C, Vankelecom H (2005) The adult pituitary contains a cell population displaying stem/progenitor cell and early embryonic characteristics. Endocrinology 146:3985-3998

49. Bernreuther C, Flitsch J, Lüdecke DK, Hagel C (2008) A 61year-old man with hyponatremia. Brain Pathol 18:283-287

50. Civit T, Pinelli C, Klein M, Auque J, Baylac F, Hepner H (1997) Intrasellar schwannoma. Acta Neurochir (Wien) 139:160-161

51. Esposito F, Cappabianca P, Del Basso De Caro M, Cavallo LM, Rinaldi C, de Divitiis E (2004) Endoscopic endonasal transsphenoidal removal of an intra-suprasellar schwannoma mimicking a pituitary adenoma. Minim Invas Neurosurg 47:230-234

52. Goebel HH, Shimokawa K, Schaake T, Kremp A (1979) Schwannoma of the sellar region. Acta Neurochir (Wien) 48:191-197

53. Guenot M, Bataille B, Wager M (1994) Intrasellar neurinoma: apropos of the case and review of the literature. Neurochirurgie 40:263-266 (French)

54. Honegger J, Koerbel A, Psaras T, Petrick M, Mueller K (2005) Primary intrasellar schwannoma: clinical, aetiopathological and surgical consideration. Br Neurosurg 19:432-438

55. Krayenbühl N, Heppner F, Yonekawa Y, Bernays RL (2007) Intrasellar malignant peripheral nerve sheath tumor (MPNST). Acta Neurochir (Wien) 149:201-205

56. Maartens FN, Ellegala BD, Vance LM, Lopes BMS, Laws RE Jr (2003) Intrasellar schwannomas: report of two cases. Neurosurgery 52:1200-1205

57. Moreland BD (2006) Intrasellar pituitary schwannoma. J Clin Neurosc 13:771-774

58. Perez TM, Farkas J, Padron S, Changus EJ, Webster LE (2004) Intrasellar and parasellar cellular schwannoma. Ann Diagn Pathol $8: 142-150$

59. Perone TP, Robinson B, Holmes SM (1984) Intrasellar schwannoma: case report. Neurosurgery 14:71-73

60. Whee SM, Lee JI, Kim JH (2002) Intrasellar schwannoma mimicking pituitary adenoma: a case report. J Korean Med Sci 17:147-150

61. Wilberger JE (1989) Primary intrasellar schwannoma: case report. Surg Neurol 32:156-158

62. Bleys RLAW, Janssen LM, Groen GJ (2001) The lateral sellar nerve plexus and its connections in humans. J Neurosurg 95:102110

63. Ulrich H, Tien RD (1998) Tumors of the cranial, spinal and peripheral nerve sheaths. In: Bigner DD, McLendon RE, Bruner JM (eds) Russell and rubinstein's pathology of tumours of the central nervous system, vol 2, 6th edn. Edward Arnold, London, pp 141-193

64. Koutourousiou M, Seretis A, Kontogeorgos G (2009) Intra-sellar schwannoma co-existing with GH-secreting pituitary adenoma. Acta Neurochir (Wien). doi:10.1007/s00701-009-0304-7

65. Freda PU, Silverberg SJ, Post KD, Wardlaw SL (1992) Hypothalamic-pituitary sarcoidosis. Trends Endocrinol Metab 3:321325

66. Thodou E, Asa SL, Kontogeorgos G, Kovacs K, Horvath E, Ezzat S (1995) Case seminar: lymphocytic hypophysitis: clinicopathological findings. J Clin Endocrinol Metab 80:2302-2311

67. Newman LS, Rose CS, Maier LA (1997) Sarcoidosis. N Engl J Med 336:1224-1234 